\title{
Avaliação Microbiológica de Carcaças de Frangos Comercializadas Na Cidade do Rio de Janeiro, Brasil
}

Jorge Gonçalo Caldeira Nunes de Matos (I), Amanda Portela

Queiroga (I), Carlla Cristhina de Oliveira P. Bindi dos Reis (I), Fernanda Ferreira Maciel (I), Angela Corrêa de Freitas-Almeida (I), Mara Lucia Penna Queiroz (I)

(I) UERJ/FCM/DIMI - Universidade do Estado do Rio de Janeiro (Boulevard 28 de Setembro, 87 fundos 3a. andar CEP: 20551-030)

\section{Resumo}

Hoje, no Brasil, a carne de frango é a mais consumida pela população. $\mathrm{O}$ aumento da produção levou o país a ser o maior exportador mundial e o $3^{\circ}$ maior produtor (2013). De acordo com a RDC 12/2001, o alimento é considerado próprio para o consumo humano quando apresentar até $10^{4}$ $\mathrm{NMP} / \mathrm{g}$ de coliformes termotolerantes. O gênero Salmonella é comum em carne de aves e como os procedimentos usados pela indústria não garantem a eliminação da bactéria, a RDC 13/2001 determina incluir na rotulagem destes produtos as instruções de uso, preparo e conservação. O objetivo deste estudo foi avaliar a qualidade higiênico-sanitária de carcaças de frangos à venda no varejo (supermercados) na cidade do Rio de Janeiro. Foram coletadas 45 carcaças de frango congeladas de 3 marcas (A, B e C), as 3 de distribuição nacional e 1 internacional (A) e outra de produção orgânica (B). Na coleta foram observados o estado da embalagem e temperatura do freezer. As amostras foram transportadas a $\pm 0^{\circ} \mathrm{C}$ para $\mathrm{o}$ Laboratório e colocadas a $\pm 4^{\circ} \mathrm{C}$ para o descongelamento. Após $20 \mathrm{~h}$, foi feita a limpeza (álcool 70\%) e a retirada da embalagem, descartando os miúdos. Cada carcaça foi pesada e colocada num saco polipropileno, adicionada água peptonada tamponada (APT) e massageada por 15 minutos. Após, a APT (AE - água de enxaguadura) foi vertida para um frasco esterilizado. Foram retirados $25 \mathrm{~mL}$ da AE e transferidos para 225

\footnotetext{
Referência:

Jorge Gonçalo Caldeira Nunes de Matos, Amanda Portela Queiroga, Carlla Cristhina de Oliveira P. Bindi dos Reis, Fernanda Ferreira Maciel, Angela Corrêa de Freitas-Almeida, Mara Lucia Penna Queiroz. Avaliação Microbiológica de Carcaças de Frangos Comercializadas Na Cidade do Rio de Janeiro, Brasil. In: Anais do 12을 Congresso Latinoamericano de Microbiologia e Higiene de Alimentos - MICROAL 2014 [= Blucher Food Science Proceedings, num.1, vol.1]. São Paulo: Editora Blucher, 2014. DOI 10.5151/foodsci-microal-135
} 
$\mathrm{mL}$ de água peptonada $0,1 \%$ para realização da diluição inicial (10-1). Foi realizada a estimativa do $\mathrm{NMP} / \mathrm{g}$ de coliformes termotolerantes. $\mathrm{O}$ isolamento de enterobactérias foi realizado através de semeadura em ágar EMB. O restante da AE, após repouso por 60 minutos, foi diluída $\left(10^{-1}\right)$ e incubada a $37^{\circ} \mathrm{C} / 20 \mathrm{~h}$ para o isolamento de Salmonella. Após, o crescimento foi transferido $(1 \mathrm{~mL})$ para tubos contendo caldo selenito e RapapportVassiliadis, incubados em banho-maria a $42^{\circ} \mathrm{C} / 20 \mathrm{~h}$. Após, ambos os caldos foram semeados em ágar SS e ágar Hektoen, incubados a $37^{\circ} \mathrm{C} / 20 \mathrm{~h}$. Os nossos resultados indicaram que $100 \%$ das carcaças estavam próprias para o consumo humano. Contudo, observamos que as marcas de produção intensiva (A e C) apresentaram valores mais elevados de NMP/g de coliformes termotolerantes e foram as únicas com embalagens degradadas. Foram recuperadas 201 cepas de enterobactérias $(A=53 ; B=52 ; C=76)$, entre estas, 12 com diagnóstico presuntivo de Salmonella spp. $(\mathrm{A}=2 ; \mathrm{B}=8$; $\mathrm{C}=2$ ), isoladas em maior número da marca de produção orgânica.

Palavras-Chave: qualidade microbiológica, carcaças de frango, enterobactérias

Agência de Fomento: CAPES; CETREINA/SR-1/UERJ 